\title{
The educational effectiveness of serious games
}

\section{L'efficacité pédagogique des jeux sérieux}

\section{La eficacia educativa de los juegos serios}

\author{
Hassen Ben Rebah, IT Technologist \\ ISET Mahdia, Tunisia \\ ben_rebah_h@yahoo.fr \\ Rachid Ben Slama, IT Technologist \\ ISET Mahdia, Tunisia \\ rachid.benslama@yahoo.fr
}

\begin{abstract}
A serious game is a computer application that combines a serious intention of a pedagogical, informative and a communicational type with playful springs of the video game (want to win, collaboration, competition, strategy). This two-dimensional approach has transformed the game from a simple means of entertainment to a robust-integrated tool growing in the world of training and learning. Serious games include the engagement of video games with the worlds of educational and computer simulation to integrate the user in a safe and entertaining learning environment. Many techniques have been used to ameliorate computer graphics and technology in the last few years to make this type of game more adaptive to the learning context. In this study, we are interested in presenting the pedagogical contributions of serious games as well as the different possible approaches of their integration in a learning situation and this is based on a variety of case studies and examples of experimentation. We will start with definitions of other video games that have some valuable characteristics of learning in order to contrast and relate them with serious games. Subsequently, we discuss the definition of serious game and the benefits of its use in education. We will, then, examine approaches to integrate serious games into classrooms with an emphasis on the assets and liabilities of each approach. To finish, we conclude on the trends that will follow the serious games technology in the educational field as well as some recommendations to be taken into consideration in order to better exploit these tools in a pedagogical context.
\end{abstract}

Keywords: serious games, benefits, situated learning, intrinsic motivation, trial and error method, adaptive serious games 
Un jeu sérieux est une application informatique qui combine une intention sérieuse de type pédagogique, informatif ou communicationnel avec des ressorts ludiques du jeu vidéo (envie de gagner, collaboration, concurrence, stratégie). Cette approche bidimensionnelle a transformé le jeu d'un simple moyen de divertissement en un outil intégré robuste se développant dans le monde de la formation et de l'apprentissage. Les jeux sérieux incluent l'engagement des jeux vidéos aux mondes éducatifs et de simulation informatique pour intégrer l'utilisateur dans un environnement d'apprentissage sûr et divertissant. De nombreuses techniques ont été utilisées ces dernières années pour améliorer l'aspect infographique et technologique de ce type de jeux afin de les rendre plus adaptables au contexte d'apprentissage. Dans cette étude, nous nous intéressons à présenter les contributions pédagogiques des jeux sérieux ainsi que les différentes approches possibles de leur intégration en situation d'apprentissage à partir de plusieurs études de cas et d'exemples d'expérimentation. Nous commencerons par la définition de quelques modalités de jeux vidéo présentant des caractéristiques d'apprentissage précieuses afin de les mettre en contraste et en relation par rapport aux jeux sérieux. Nous discuterons ensuite la définition des jeux sérieux ainsi que les avantages de leurs utilisations dans le domaine de l'éducation. Nous vérifierons par la suite les approches d'intégration de ce type de jeu en classe toute en mettant l'accent sur les apports positifs et négatifs de chaque approche. Enfin, nous présentons les tendances qui suivront la technologie des jeux sérieux dans le domaine de l'éducation ainsi que quelques recommandations à prendre en compte afin de mieux exploiter ces outils dans un contexte pédagogique.

Mots-clés: jeux sérieux, avantages, apprentissage situé, motivation intrinsèque, méthode d'essai et d'erreur, jeux sérieux adaptatifs

\section{RESUMEN}

Un juego serio es una aplicación informática que combina una intención seria de tipo pedagógico, informativo y comunicativo con fuentes lúdicas del videojuego (ganas de ganar, colaboración, competencia, estrategia). Este enfoque bidimensional ha convertido el juego de un simple medio de entretenimiento a una herramienta robusta e integrada desarrollada en el mundo de la formación y del aprendizaje. Los juegos serios añaden la atracción de los videojuegos en el mundo educativo y de simulación informática para integrar al usuario en un entorno de aprendizaje seguro y entretenido. En los últimos años, se han utilizado muchas técnicas para mejorar los gráficos y la tecnología de este tipo de juegos, para que se adapten mejor al contexto de aprendizaje. En este estudio, nos interesa presentar las contribuciones pedagógicas de los juegos serios, así como los diferentes enfoques posibles de su integración en una situación de aprendizaje a partir de varios estudios de casos y ejemplos de experimentación. Comenzaremos definiendo videojuegos con características valiosas de aprendizaje para contrastarlos y relacionarlos con los juegos serios. Posteriormente, trataremos la definición de juego serio y los beneficios de su uso en educación. Luego, verificaremos los enfoques para integrar juegos serios en las aulas poniendo énfasis en los aspectos positivos y negativos de cada enfoque. Para finalizar, concluiremos con las tendencias que seguirán la tecnología de los juegos serios en el campo educativo, así como con algunas recomendaciones a tener en cuenta para explotar mejor estas herramientas en un contexto pedagógico.

Palabras clave: juegos serios, beneficios, aprendizaje situado, motivación intrínseca, método de prueba y error, juegos serios adaptativos 


\section{Introduction}

The game has long been used as a teaching aid that better allows promoting or facilitating learning. This pedagogical orientation has been argued by several research works that affirm the positive impact of games in the field of education. For example, the works of Piaget (1994) highlighted the importance of game for the development of many competences among learners such as kinetic, symbolic, normative, social and communicational skills. In the same context, other authors have noted the interest of games for the development of the imagination (Mellier, 2007) and the creative thinking skill (Frossard, Barajas \& Trifonova, 2012).

Since the 1970s, video games have started to gradually replace traditional games as an entertainment or enjoyment activity. This migration has improved more and more the place of this technological artifact among the young generation qualified as "digital native". A recent study of young North Americans (Rideout, Foehr \& Roberts, 2010) shows that, on a little over 7 hours and a half daily exposure to the media, 1 hour and half are spent playing digital games. The study also shows that the use of games is developing today for both girls and boys, mainly on mobile devices such as mobile phone or console and on platforms offering multiplayer online games.

Several research works have implied that some of those video games can be used for more serious aims especially because that this kind of digital games can ameliorate the attention, the cognitive control, the visuo spatial processing as well as the flexibility of users (Spronck, Ponsen, Sprinkhuizen-Kuyper \& Postma, 2006) and they can have a positive effects on learning (Baranowski et al., 2003) and the socialization of adolescents (Shaftel, Pass \& Schnabel, 2005).

Thus, the first decade of the 2000s witnessed the success of a denomination, that of serious game to designate useful computer applications using the springs of the video game. This type of game first appeared in the United States and popularized by America's Army ${ }^{1}$ in order to seduce young Americans for recruitment by the army (Lavigne, 2014). Over time, these games have become more and more prevalent (Tobias, Fletcher, Dai \& Wind, 2011; Vogel, Vogel, Cannon-Bowers, Bowers, Muse \& Wright, 2006) and used as communication, training or recruitment tools (George, Michel, Serna \& Bisognin, 2014).

In recent years, the field of education becomes among the sectors where this type of game is increasingly taking its place (Checola, 2008) since there is a big number of educational games, as well as a number of entertainment games that have been effectively used for educational and training purposes (Kirriemuir \& McFarlane, 2004). For example, according to the International Data Corporation (IDC) in the US, $40 \%$ of e-learning applications use serious games in 2008 (Alvarez \& Michaud, 2008). These serious games are considered by some researchers as a "revolution" (Lavergne \& Dambach, 2010) allowing to make the learning process more flexible and easier (Kasbi, 2012). According to Squire (2008) and Cohard (2013), learning through video games is a new model of e-learning that is less interesting in content and more in the design of the experience that stimulates modern ways of thinking, acting and to appear in the world.

It is obvious that the use of serious games in educational settings can increase the probability of providing students with authentic learning because they create a virtually immersive context wherein students are allowed to experience things and repeat experimentations that are unlikely to be realized in their everyday lives (Cheng \& Annetta, 2012).

In this context, the use of such games can ameliorate students'learning motivation (Papastergiou, 2009), simplify knowledge acquisition (Miller, Chang, Wang, Beier \& Klisch, 2011), increase task engagement

${ }^{1}$ America's Army: www.americasarmy.com 
(Annetta, Minogue, Holmes \& Cheng, 2009) and enhance specific capacities like problem solving and cooperation (Sánchez \& Olivares, 2011) by appropriately visualizing abstract ideas and key principles of several topics in the game environment.

In this paper, we will begin by reviewing the video game modalities for learning while emphasizing the aspects of serious games and their pedagogical contribution when they are integrated into a learning situation. We will also expose the different approaches of integration of serious game in class. Finally, we conclude with describing models and trends of serious games for education presented by some researchers as well as some recommendations to better exploit these tools in a pedagogical context.

\section{Video game modalities for learning}

Video games, with the variety of their genres (action, adventure, education, simulation, etc.) can be considered as a fun and engaging alternative learning and transfer tool. Their integration into the training and education cycles requires a good knowledge of their different modalities in order to identify with relevance the type of games that meets appropriately the learning situation. Schmoll (2017) presents an example of the different modalities of the possible play-educational use of video games during a learning situation on a continuum (Figure 1) ranging from the most dominant serious dimension of the game (on the left) to the most dominant playful one (to the right).

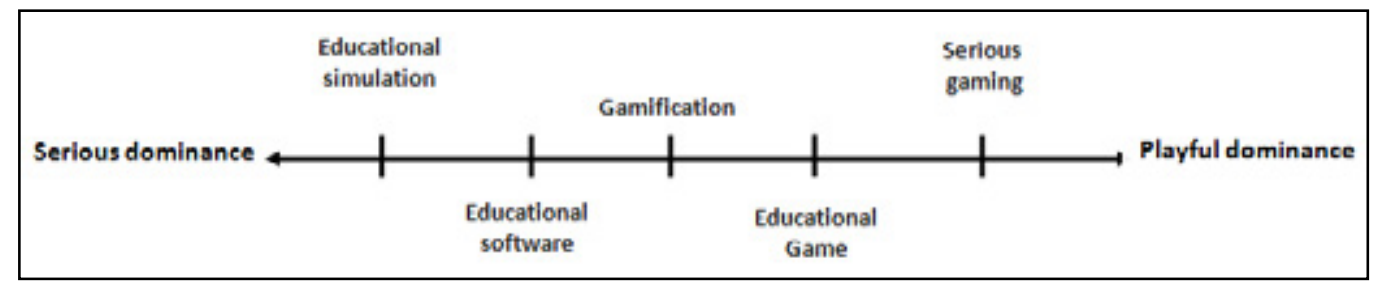

Figure 1. Video games modalities for learning (Schmoll, 2017, p. 4)

\section{Educational simulation}

Referring to Neufeldt \& Sparks (2002) to simulate is "to look or act like". In general, simulations are models that express complex real-world systems. A simulation is used to analyze specific systems, developmental models in learners, or research artificial environments (Narayanasamy, Wong, Fung \& Rai, 2006). In the same context, an educational simulation is based on an internal model of a real-world system or phenomena in which some elements have been simplified or omitted in order to facilitate learning (Lunce, 2006).

Trollip et alessi (2001) announce that educational simulations have several advantages over other instructional methodologies and media, for example: students often find active participation in simulations more interesting, intrinsically motivating and nearer to real world experiences than other learning modalities. In the same way, simulations permit students to experience phenomena which may be hazardous, costly or even impossible to observe in the real world. In addition, simulations can accommodate a wide range of instructional strategies, containing microworlds, scientific discovery learning, virtual reality, laboratory simulations, role playing, case-based scenarios, and simulation gaming. 
Van Horn (2007) suggests that games are different from simulations because games include an objective or challenge. Yet, some researchers suggest that simulations also incorporate objective and the real difference is the main purpose of the game or simulation; games are purely intended for entertainment and simulations are meant to foster learning and training (Becker \& Parker, 2006). In this category, we can mention Simulang ${ }^{2}$ a 3D serious game developed in 2012 and dedicated to learning English.

\section{Educational software}

Educational software or edutainment software can be considered as the root of the video game of learning, i.e. it is on a digital medium and it presents an educational content, by inserting a fun-like atmosphere with challenges and rewards (Natkin, 2009). It means, also according to Egenfeldt-Nielsen (2007), that learning occurs by software that both educates and entertains.

Edutainment software (contraction of education and entertainment) mainly depends on technology, especially computer software (Rapeepisarn, Wong, Fung \& Depickere, 2006). Most of the time, It exists in the form of educational electronic games aimed at teaching and learning concepts and processes. It is a game type that is based on visuals and narratives or game formats, but also includes some kind of learning goals, such as concepts and processes (Buckingham \& Scanlon, 2000).

Edutainment software is generally designed for a young audience, like the famous collection of software Adi (Coktel Vision, Mindscape), published in the 1990s.

\section{Gamification}

According to Deterding, Dixon, Khaled \& Nacke (2014) while serious game describes the design of games in its own right for non-entertaining purposes, gamified applications only incorporate game elements. In other words, the principle of gamification consists of integrating playful springs into a non-playful context, whether digital or not. The most common are to replace objectives with challenges, to set up a reward system (badges, access to bonus activities), even competition (ranking) or to present a form of scripting with changes in level according to the progress of the user. Other authors also add that gamification is "using game-based mechanics, aesthetics and game thinking to engage people, motivate action, promote learning, and solve problems" (Kapp,2012). In this same context Kim (2015) claims that gamification can be used to promote user engagement and instruction.

An example of this gamification concept is the eBay site that use game elements to keep people engaged and encourage friendly competition between users.

\section{Educational Game}

The educational game is a type of serious game designed around one or more purely educational goals (Crawford, 1982). It offers learners an artificial environment in which a structure, contents, rules and educational objectives are integrated (Khouna, Ajana, Rhazal \& El Hajjami, 2017).It is also an experiential learning-based approach that is likely to contribute positively to student learning (Sanchez, Ney \& Labat, 2011) through the development of their skills as well as their ability to act (St-Pierre, 2010). According to Aburahma \& Mohamed (2015), the educational game can be considered as a structural method that requires the learner to participate in a competitive activity with predefined rules. It can support high-level

\footnotetext{
${ }^{2}$ https://www.simulang.biz/
} 
discussions that help the learner improve the way they communicate, the way they work with others, and their critical thinking. Some educational games are generally designed for small children and represent only a virtual replication of textbooks which makes them less effective for long-term learning or for adult learning (Rankin \& Sampayo, 2008) because of the dominance of the static aspect of the content of the game. In this category, we can find Quiz, goose-like courses, adventure sequences. etc.

As an example of an educational game, we can find the serious "Blocus"3 game of the Catholic University of Louvain for students attending the university, and especially for students who are studying human sciences (psychology, literature, law, economics, communication, etc.).

\section{Serious Gaming}

Serious gaming is the use of existing video games, usually designed for fun purposes at the origin, by assigning those learning objectives (Djaouti, 2011). In other words, it is the use of a game for purposes other than mere entertainment, whatever the original intent of its designer (Alvarez \& Djaouti, 2010). In this context, we can cite the example of the game SimCity (Maxis, 2013) that was originally designed by its designer Will Wright as an entertainment tool but some teachers who have deployed this game as support to illustrate their courses.

\section{Serious Games}

\section{Definition}

For several years, the concept of educational game has taken several meanings. The first formal definition of this concept was proposed by Abt (1970) in his book, which presented the game as a support for enriching school curricula, reducing the boundary between school learning and informal learning. In his time, a game can be a simple computer game, a basic game using the pen and paper, a board game, a role play or even an outdoor game because the video game industry has not been established, yet.

The real advent of the concept of the serious game is dated 2002 according to Sawyer, who defined this game based on the idea of connecting a serious objective to the knowledge and technologies from the video game industry. The return to literature shows the existence of several definitions of the serious game. For example, Alvarez (2007) in his thesis presents the serious game as a computer application, with the purpose is to combine at the same time serious features, in a non-exhaustive method, the teaching, the learning, the communication, or the information, with springs playful from the video game. The objective of this association is to depart from the simple entertainment to an active learning. Also and in this same context, Sauvé (2008) indicated that a serious game is a video game to which authors attach a clearly defined pedagogical goal manifested in a realistic or artificial environment composed of rules and challenges.

In addition and in a more specific way, Laamarti, Eid \& El Saddik (2014) in their study define serious games as an application based on three components: the first one is the experience because a serious game has the potential to improve the player's experience by multimodal interaction whatever the context of the game (educational, training, health, etc.). The second one is the entertainment, and the third one is the multimedia because serious game is a digital game, which contains different types of media such as text,

\footnotetext{
${ }^{3}$ http://www.blocus-thegame.be/game fr/
} 
graphics, animations, audio, etc. In addition, these authors affirm that the serious term, comes from the characteristic of the game which offers to the player an environment based on a content emanating from a know-how or an experience related to the context of the game and allowing this one to ameliorate his knowledge and his competences by interacting with the game.

It is clear from all these examples of definitions that a serious game is essentially based on three aspects namely pedagogy, technological support and playfulness because it is a game that uses the computer tool in a playful context for a pedagogical purpose.

\section{Difference between serious and video games}

In the light of the previous definitions, we can deduce that serious game is characterized by the combination of "playful" and "serious" dimensions explicitly desired by its designer. However, users can use video games generally characterized by their playful dimensions in a way that was not necessarily designed by their developer. To do this, there are two alternative methods to add the "serious" dimension to a video game: "purpose-shifting" and "mods". The first technique consists for example in adding a "serious scenario" by a teacher to an already existing video game in order to reach a definite pedagogical objective during the presentation of a lesson to his students. The second technique consists of introducing software modifications in order to adapt it to another context or another objective. As an example of mods method we can cite, Escape from Woomera ${ }^{4}$ is a software modification of the video game Half-Life ${ }^{5}$. The game scenario of Half-Life, which originally referred to fighting an alien invasion, was transformed to give "serious" information about the difficult living conditions in an Australian immigration centre. In order to clearly identify the difference between serious games and video games in a general way as well as the concept of "purpose-shifting", Jenkins et al. (2009) suggest a new category called "serious gaming" based on bringing together "purpose-shifting" and "serious game" (see Figure 2).

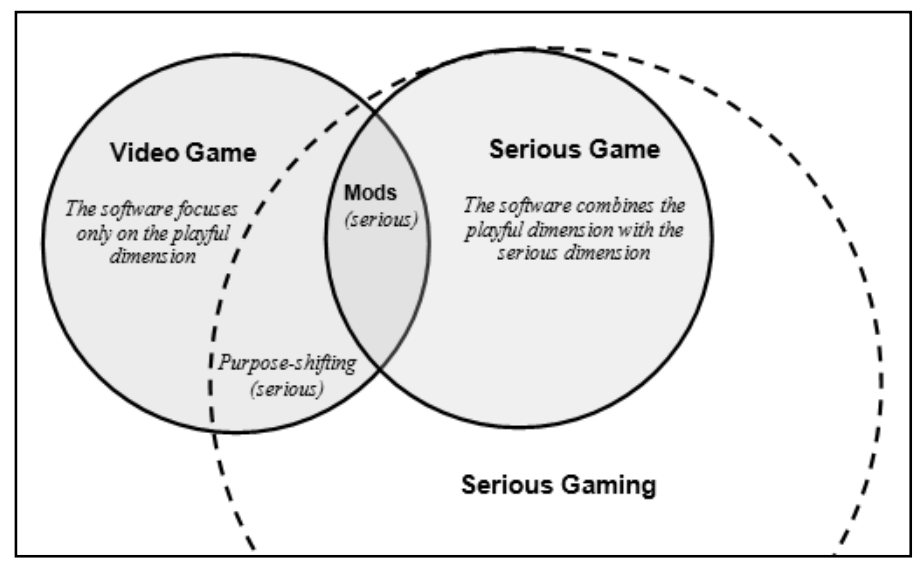

Figure 2. Relationship between video game, serious game and serious gaming (Djaouti, Alvarez \& Jessel, 2011, p. 4)

\footnotetext{
${ }^{4}$ http://serious.gameclassification.com/EN/games/1222-Escape-From-Woomera/index.html

5 http://gameclassification.com/EN/games/1223-Half-Life/index.html
} 


\section{Components of good serious games}

In a context of educational serious games, there are various perspectives in the literature what should be a good game. (Shute \& Ke, 2012) has tried to synthesize some work to define the seven key components to implement a good digital game promoting deep learning. These components are represented as follows:

- Interactive problem solving: games necessitate a continuous interaction between the user and the game, which usually implies the requirement to find a solution to several problems or issues.

- Specific goals/rules: games based on instructions to follow and goals to achieve which help the user emphasize on what and when should be done. Goals in games can be implicit or explicit.

- Adaptive challenges: good games alternate between different levels to match user's capacities. The most important games and instruction do not transcend the boundary of the user's capabilities.

- Control: a good game must permit or enhance a user's impact over gameplay, the game environment, and the learning experience.

- Ongoing feedback: good games should permanently offer data to users about their performance.

- Feedback may be explicit or implicit, and as research has showed, has good effects on learning.

- Uncertainty creates challenge and player engagement. If a game "telegraphs" its outcome, or can be considered as predictable, it will lose its importance.

- Sensory stimuli refer to the mixture of graphics, sounds, and/or storyline utilized to stimulate the senses, which do not necessitate "professional" graphics or sound to be compelling.

\section{Types and classes of serious games}

Since its appearance in 2002 , serious games have been classified into several categories using different methods and techniques. In this part, we will present some examples of these classification systems. It should be noted that the majority of the classification techniques proposed by the researchers come to remedy the shortage identified by other already existing procedures.

The first method of classifying serious games was based on a single criterion. This approach originally proposed by Sawyer \& Smith (2008) arise two categories:

- Market-based category that lists games according to their field or scope. Among the authors who have opted for this type of classification, we find Zyda ( 2005) which divide serious games essentially into five categories: Strategic Communication, Public Policy, Training \& Education, Defense and Healthcare.

- Purpose-based category that has its roots in the fact that each game is usually developed to serve a purpose. Among the authors who have opted for this type of classification are Despont (2008) which divides games into four groups: Learning Games, Advert Games, Business Games and Institutional Serious Games.

Despite the usefulness of this type of classification, the latter suffers from some limitations. For example, among the shortcomings of the market-based classification, we can mention on the one hand the discovery of new markets for serious games. On the other hand, this type of classification is able to inform the users on the field of the game but not on its contents. This kind of limit has paved the way for researchers to define other types of multi-criteria classifications (the Serious Game Taxonomy) that allow the first level to index serious games according to the purpose and the scope at the same time and this in order to obtain more refined classification categories. Like its predecessors, this taxonomy also suffers from some shortages, for example the overlap between the "market" and "purpose" categories. These problems also 
prompted Djaouti, Alvarez \& Jesse (2011) to propose a new classification approach called the G/P/S model. This classification is based on three aspects: the first aspect is the "Gameplay" which has been considered as to the way the game should be played. The second is the "Purpose" which paves the way to focuses on practical goals that the serious game must aim: the message to broadcast, the way to provide training, the manner to foster the exchange of data between the player and the game for training. And the third is the "Scope" which proposed the game following a market (education, military, health, etc.) and public (the general public to professionals). In Jantke \& Gaudl (2010), the authors focus on the importance of a taxonomical method to the scientific treatment of the science of digital games with an emphasis on serious games. The taxonomy is based on three dimensions. The first dimension is that the digital game is computer software. The second one considers the genre of the game, but the third deals with the interaction between the players and the game.

Another classification has been proposed by Ratan \& Ritterfeld (2009) regarding serious games for learning. In this context, authors review existing games which have been named as "serious" by their designers, in special databases or on review websites. All in all, they reviewed a total of 612 games and generated a classification system from the descriptions that existed for these games. Through expert review and an iterative analysis they arrived at a classification system which is made up on four dimensions: primary educational content, primary learning principle, target age group and Platform. For the "dimension of educational content", they differentiate between academic education, social change, occupation, health, military, and marketing with academic education being the most important content in the studied games, accounting for $63 \%$. For the "dimension of primary learning" principles, four interesting concepts were extrapolated: practicing skills, knowledge gain by discovery, cognitive problem solving, or social problem solving. Concerning "age groups", Ratan and Ritterfeld define four levels: preschool and below, elementary school, middle school and high school, and college, adult and senior. The analysis of platform availability showed that approximatively all games were designed for personal computers (about $90 \%)$.

Likewise, following a review of the existing classification systems, Laamarti, Eid \& Saddik (2014) proposed another taxonomy based essentially on five criteria for classifying serious games: the first one is the activity, which represents the type of action performed by the user as needed by the game. The second one is the modality that is the medium allowing the transmission of information between the computer and the player. The third one is the interface used by the player during the manipulation of the game, for example the keyboard, the mouse, the joystick, etc. The fourth one is the environment of the digital game which can be a mixture of some criteria (2D/3D, Virtual or mixed reality environment, Location awareness, Mobility, Online, Social presence) and the last one is the scope which represents the different application area of the game. In the other way, Djaouti, Alvarez, Jessel, Methel \& Molinier (2008) propose another videogames classification that depends on the concept of "Game play Bricks", where the different inclusion of the "fundamental elements" correspond to the different rules and objectives of videogames. They also defined two different kinds of game rules: the rules that pave the way to the player to manipulate the elements of the game, and, at a higher level, the rules identifying the objective of the game.

\section{The pedagogical virtues of serious games}

The serious game is an educational tool that offers students an environment, which promotes learning. However, many cases of study by researchers in this field (Mouaheb, Fahli, Moussetad \& Eljamali, 2012; Przybylski, Rigby \& Ryan, 2010; Wouters, Van Nimwegen, Van Oostendorp \& Van Der Spek, 2013) have shown the following major benefits: 


\section{The intrinsic motivation of learners}

The Intrinsic motivation is the most self-determined level of motivation that an individual can reach. In this case, the individual engages in an activity for reasons of pleasure and satisfaction that he will feel when he practices it (Deci, 1971; Vallerand \& Halliwell, 1983).In general, this is a voluntary engagement and it can be explained by the personal interest that the activity represents for the individual (Vallerand, Blais, Brière \& Pelletier, 1989). The return to literature shows the existence of some researches that have shown that the serious game object itself can bring intrinsic motivation gain for learners (Garris, Ahlers \& Driskell, 2002; Malone, 1981; Wastiau, Kearney \& Van den Berghe, 2009; Wix, 2012).

Malone \& Lepper (1987) have clearly identified four key factors that make a learner intrinsically motivated in a learning situation involving a video game, namely challenge, curiosity, control and imagination (fantasy):

- the challenge is mainly the activities that are neither too difficult nor too easy for the learner-player;

- curiosity, which takes the form of activities with elements of surprise and novelty from a cognitive or sensory point of view;

- the control of a specific environment that is defined by the presence of a large number of options, by the probability that the reactions of the system are the result of its decisions and by the force of the impact of each of his actions;

- a fictional or imaginary world that responds to emotional needs by allowing the player to experience rewarding experiences such as power or success.

To these elements, Przybylski, Rigby \& Ryan (2010) add two other factors in video games that can also ameliorate the motivation of learners which are autonomy and competence. The autonomy means the feeling to master the game and guide its progress towards the desired goal to foster the sense of equifinality among the player. The competence is essentially the ability to progress in the game so that the player could continually improve his skills with an increasing challenge.

It should also be noted that among the main attractions of video games is their ability to strongly engage players in an activity. According to Foreman (2003) "Games exposed players to deeply engaging, visually dynamic, rapidly paced, and highly gratifying pictorial experiences that make almost any sort of official schoolwork (especially when mediated by a reading or text) seem boring by comparison".

When engaged in play, the student may forget that he is working on the integration of new knowledge and is motivated by his challenge to play and win. This new situation where the learner reaches the maximum of pleasure is described by Rieber, Smith \& Noah (1998) as a state of "Flow". According to Csikszentmihalyi (1990), the Flow corresponds to a psychological and physiological state characterized by a feeling of mental fluidity linked to an intense concentration in an activity. This type of state is usually accompanied by an impression of discovery and a creative feeling that takes the player to another dimension and pushes him to become more efficient at producing significant cognitive efforts.

\section{Situated learning}

According to Jonassen, Campbell \& Davidson (1994), situated learning usually occurs when learners practice tasks that correspond to real-world situations. As a result, knowledge is determined by its counterpart in the real world in its context. It is considered inert if it is devoid of its context, that is to say, even if the learner has learned new concepts, he is unable to exploit them if he does not find the real context to do so. From a constructivist perspective and using Piaget's work, individuals acquire knowledge 
through the interaction of their innate abilities with the environment. Learning is generally considered to be an active process where the learner is able to develop his or her knowledge in an autonomous way while basing himself on the experience of interacting with the environment in which he has been immersed. One of the determining factors of this construction is cognitive conflict (Kozanitis, 2005). According to Fréte (2015) the game does offer the possibility of anchoring learning in real or fictional situations allowing the learner to feel engaged in a process of problem solving by performing tasks that will interest him from the start. These actions planned by the learner to solve the problems he is confronted are linked by the playful metaphor and fed by the objectives, the context and the challenge of the game.

In another strand, situated learning also relies on social interaction and collaboration among learners within a single practical community (Lave, 1988). According to Wenger (2005), this community is defined as a group of people who work together and who are in fact led to constantly invent local solutions to the problems encountered in their professional practices.

Indeed, a serious game puts the learner in the role of a character who must find the best solution to solve a situation-problem. To do this, he can then question expert characters encountered in the game. These experts ask him questions and make remarks that he will use to answer the problem he has to solve. According to Sanchez, Ney \& Labat (2011), a play-educational game offers learners the opportunity to interact with others to collaborate.

\section{Learning from mistakes}

Thorndike (1931) considered that learning was done by "trial and error". To prove his method, the American psychologist resorted to a hungry cat placed in a box, outside of which was placed food. After several trialand-error tests, Thorndike found that the animal improved its performance and was able to put in place strategies to obtain adapted behaviors in order to access the food. As a consequence, it is, indeed, possible to identify this type of test-error behavior in humans. In this context, Astolfi (1997) stated that "error, then, becomes constructive instead of destructive".

This type of learning has been integrated more and more in the majority of serious games based on the fact that the new generation of qualified "digital native" has a greater willingness to take the risk and learn through its errors (Beck \& Wade, 2004). According to Higgins (2000) and Whitebread (1997), this type of game helps to support the development of logical thinking and problem solving for the learner since it offers him a virtual space of experimentation in which he can check his thinking abilities. As a result, and during interaction with the game, the learner mentally constructs scenarios that can lead to positive or negative feedback to overcome challenges or obstacles. In case of error, the learner must refine his scenario until finding the right solution. This kind of simulation developed by the player during the different sequences of the game improves his creativity and concentration (Michel, Kreziak \& Heraud, 2009). However, in order to guarantee the efficiency of this simulation, it is important that there will be good interactivity between the learner and the trainer during the learning situation. Thus, a good Serious Game offers players immediate feedback based on their proposed scenarios in order to help them find the right solution (Sanchez, Ney \& Labat, 2011).

To better understand the relationship between the structure of the game and its pedagogical contributions in terms of learning, the Table 1 presents three game models, their pedagogical advantages as well as the method of learning developed by its creator in order to promote these objectives. 
Table 1

Example of same serious games pattern and its educational benefits

\begin{tabular}{|c|c|c|}
\hline $\begin{array}{l}\text { Serious game } \\
\text { pattern }\end{array}$ & Educational benefits & Learning method \\
\hline $\begin{array}{l}\text { The role-play scenario is built around } \\
\text { role-playing activities, guided by } \\
\text { rules. The players choose the } \\
\text { actions of the character they embody } \\
\text { according to the objectives to be } \\
\text { attained and the alliances with the } \\
\text { other characters, thus creating an } \\
\text { infinity of possible stories for the } \\
\text { game. }\end{array}$ & $\begin{array}{l}\text { Improve social skills } \text { (e.g. } \\
\text { communication, negotiation) and } \\
\text { understand complex topics that } \\
\text { involve multiple actors. This type of } \\
\text { game can be used to create } \\
\text { participatory simulations to teach } \\
\text { mechanisms, such as the spread of a } \\
\text { disease, as in the game Disease } \\
\text { Simulation. }\end{array}$ & Intrinsic learning \\
\hline $\begin{array}{l}\text { The investigative game scenario is } \\
\text { built around a central enigma that } \\
\text { players must solve by collecting and } \\
\text { analyzing problem situations. The } \\
\text { model is very similar to the case- } \\
\text { based learning method. Indeed, it } \\
\text { consists of posing a problem to the } \\
\text { learners, inspired by a real situation, } \\
\text { placing them in the position of the } \\
\text { decision-maker. }\end{array}$ & $\begin{array}{l}\text { We believe that this model of play is } \\
\text { thus perfectly adapted to train the } \\
\text { learners to use their theoretical } \\
\text { knowledge on concrete cases. These } \\
\text { cases can cover a wide variety of skills } \\
\text { such as finding the pathology a patient } \\
\text { is suffering from, identifying the cause } \\
\text { of a breakdown, or finding the best } \\
\text { solution for a divorce. The game } \\
\text { allows learners to use decision- } \\
\text { making tools (e.g. brainstorming, } \\
\text { criteria grid) on a real complex case. }\end{array}$ & Situated learning \\
\hline $\begin{array}{l}\text { A treasure hunt game is a game in } \\
\text { which players search for one or more } \\
\text { hidden objects, using a sequence of } \\
\text { clues. }\end{array}$ & $\begin{array}{l}\text { This type of game encourages players } \\
\text { to explore and appropriate the } \\
\text { physical environment; it is particularly } \\
\text { suitable for teaching the } \\
\text { characteristics of real objects in their } \\
\text { natural contexts. }\end{array}$ & $\begin{array}{l}\text { Learning } \\
\text { mistakes }\end{array}$ \\
\hline
\end{tabular}

It should be noted that the "on the ground" use of these three approaches is ideal to the educational integration of serious game. Indeed, according to studies on teaching practices (Wastiau et al., 2009; Wix, 2012), "Intrinsic motivator learning" have a profoundly greater effect on engagement; it is through intrinsic interests that people achieve great things. The ideal class would have every student engaged in productive, stimulating and interesting work $100 \%$ of the time. In contrast with most classroom learning activities that involve abstract knowledge, which is, and out of context, Lave (1991) argues "learning is situated"; that is, as it normally occurs, learning is embedded within activity, context and culture. It is also usually unintentional rather than deliberate. Lave \& Wenger (1990) call this a process of "legitimate peripheral participation". "Learning from mistakes", said the inventor Thomas Edison in reference to his experiments: "I have not failed. I've just found 10,000 ways that won't work." As such, he has been encouraged to try new things, take risks, and learn through trial and error.

\section{Approaches to integrate serious games in class}

In the context of a university or school education, serious games can be considered as an additional pedagogical tool, which allows the teacher to improve the acquisition of knowledge and skills by students while promoting experiential learning and the collaborative approach among learners. To integrate this type of game in an effective way by the teacher as part of his course and enjoy its benefits appropriately, 
it is necessary that the latter appropriates this new teaching support and to understand the means and the types of scenario to implement there. Djaouti (2016) proposes three different approaches for a teacher to apply serious games into his pedagogical practices:

\section{Using existing serious games as a teaching aid in class}

This is the least expensive approach where the teacher uses a serious game already existing whether commercial or free. For example, the Singstar PS3 karaoke game (SCE London Studio, 2008) is used as a teaching aid to apply on the pronunciation of English among college students. Otherwise, Buzz! Quiz TV game (Relentless Software, 2008) is hijacked by history and geography teachers in order to come back to notions discussed in class.

\section{Creating serious games by the teacher}

In this approach, the teacher creates a special serious game that fully responds to his teaching practices without forgetting the specificities of a game as a means of entertainment. Contrary to the first one already mentioned, the creation of a serious game is a generally an expensive project that requires the involvement of several specialists namely pedagogues, programmers, designers, etc. According to Michaud, Alvarez, Alvarez \& Djaouti (2012), the average cost of realizing a Serious Game is around $150,000 €$ for 18 months of work. To reduce the cost of this type of approach, teachers can take charge of their own games and especially those who master the programming, or they can use software (e.g. RPG Maker $)$ or online solutions (e.g. Sploder ${ }^{7}$ ) in order to create a simple video game. In this same context, teachers can use the " mods" method which usually involves new levels, characters, or objects for a given game (McArthur \& Teather, 2015). However, this technique makes it possible to transform certain entertainment video games of into serious games (Monterrat, Lavoué and George, 2012). For example Thierry Labregère ${ }^{8}$ is a French teacher, working in primary school, who has created about thirty serious games that he uses with students for the learning mathematics and French (e.g. Bob Courvite series, The castle of letters, Count the balls, etc.).

\section{Creating serious games by the learners}

This third approach is to offer learners the opportunity to create their own serious games based also on the "modding" or the exploitation of some dedicated software. In this case, the teacher proposes to create a game on a given theme to his students, which requires from their parts the acquisition of new knowledge and skills. This type of activity is generally applied as part of an "active learning" or "project-based learning" method that requires the learner to be more autonomous. As an example of work that applies this approach, we can cite the experiment carried out by the researcher Kafai (1994) near a group of students in a primary school, which consists of making a video game to learn the concept mathematical "fraction". The result of the experiment has shown that students who have taken the initiative to develop their own game show higher quality learning.

Despite the usefulness of these three approaches and their pedagogical contributions, each has its assets and liabilities that can be summarized in the following table:

\footnotetext{
${ }^{6}$ http://creatools.gameclassification.com/FR/creatools/68-RPG-Maker-VX/index.html

${ }^{7}$ http://www.sploder.com/

${ }^{8} \mathrm{https}: / /$ thierry-labregere.pagesperso-orange.fr/
} 
Table 2

Summary of the three approaches to integrate serious games in class

\begin{tabular}{|c|c|c|c|c|}
\hline Approach & Cost & $\begin{array}{c}\text { Speed of } \\
\text { development }\end{array}$ & Pedagogy & Entertaiment \\
\hline $\begin{array}{c}\text { Using already existing serious games as a } \\
\text { teaching aid in class }\end{array}$ & - & ++ & + & +++ \\
\hline Creating serious games by the teacher & ++ & -- & +++ & ++ \\
\hline Creating serious games by the learners & + & -- & +++ & +++ \\
\hline -: Low; +: Medium
\end{tabular}

\section{Models and trends of serious games for education}

\section{Models of serious games for education}

The games are in themselves encouraging and can be used successfully for this purpose. The design and use of digital serious games is based on a certain theoretical basis in the constructivist learning theories, which consider that knowledge is created by experience while exploring the world and carrying out activities (e.g. Krathwohl, Bloom \& Masia, 1964; Dewey, 1933; Montessori, 1946; Kolb, 1984). "Constructivism emphasizes the importance of the learner to make his own knowledge". Nevertheless, Kirschner, Sweller \& Clark (2006) argue for the importance of orientation, particularly for novices.

Implications on game design involve the creation of virtual environments, typically 3D, where the player can gain knowledge through exploration and by doing, possibly in collaboration with other people; Analyzing user experience, Rowe, Shores, Mott \& Lester (2010) report that:

high-achieving science students tended to demonstrate greater problem-solving efficiency, reported higher levels of interest and presence in the narrative environment, and demonstrated an increased focus on information gathering and information organization gameplay activities.

However, "lower-achieving microbiology students gravitated toward novel gameplay elements, such as conversations with non-player characters and the use of laboratory testing equipment". Observing the gameplay, the authors noticed that:

high-achieving students tended to utilize more traditional science resources such as textbooks and worksheets while attempting to solve the presented mystery. In contrast, low-achieving students employed the help of expert nonplayer characters and virtual lab equipment to aid in their quest.

These observations seem to focus on the fact that learning is a complex activity that requires graduality and needs several steps that have to be supported by various tools (e.g., paper and digital, reading and writing, etc.). In fact, Figure 3 shows two pedagogical models that look complementary and useful to analyze serious games (Hauge et al., 2013). 


\section{Learning goals in the revised Bloom taxonomy}

Remembering Understanding

Applying

Analysing

Evaluating

Creating

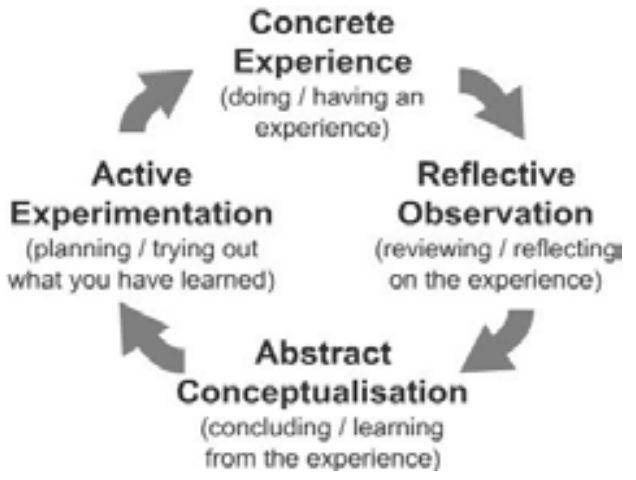

Concrete

Experience

doing / having an

experience)

\begin{abstract}
Reflective
Observation

reviewing / reflecting:
\end{abstract}

(planning / trying out

Figure 3. The Revised Bloom taxonomy and the Kolb’s learning stages (Kolb, 1984)

The Revised Bloom Taxonomy (Anderson et al, 2001) which is a popular cognitive approach to Serious game evaluation (Kolb, 1984) and the Kolb's Experiential Learning model (Nonaka, Toyama \& Konno, 2000) (See Figure 3), which "systemizes the work rooted on Piaget's cognitive developmental genetic epistemology (Piaget, 1929), on Dewey's philosophical pragmatism (Dewey, 1933), and on Lewin's social psychology, putting the experience at the centre of the learning process". Good serious game should allow users to make important experiences, thus normally sustaining the experiential learning pedagogical paradigm.

\section{Trends: Adaptive serious games}

In general, games are more or less difficult to play. As a result, "the players become frustrated if the games are too difficult and become bored if they are too easy" (Rasim, Langi, Munir \& Rosmansyah, 2016). Therefore, the developers are thinking about creating serious games while automatically taking into account the level of players to stay in a comfortable situation "Golden path or optimum corridors" (see in Figure 4). These serious games have the tendencies to become adaptive. We talk about "adaptive serious game" which is a type of game that requires non-player character (NPC) and player character (PC) where NPC can fit its response to the PC (Bieliková, Divéky, Jurnečka, Kajan \& Omelina, 2008).

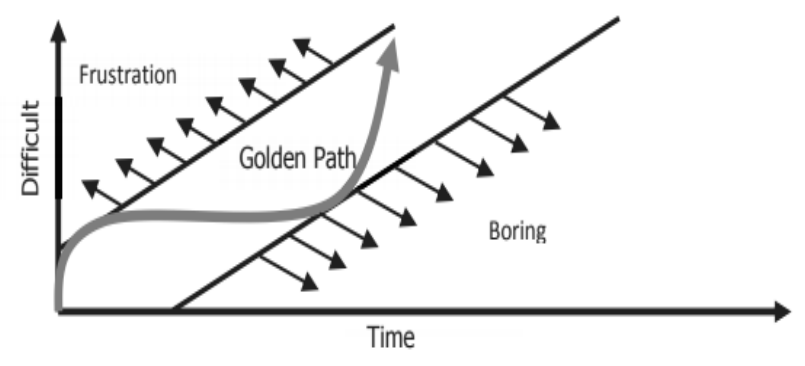

Figure 4. Optimum Corridors (Thomas \& Young, 2010, p.2) 
In general, the tutor can intervene in class to regulate the learning process to work better with each learner while taking into account his initial representation (profile, learning style, etc.). Also in a digital context, serious games must have an adaptive engine to properly control the user's status. This adaptive engine can be seen in terms of the frameworks and the algorithms. Frameworks combine rules based, plan based, organization description based, proficiency of player based, learning style and cognitive state based. Algorithms combine agents based and non-agent based. In this context, Rasim et al. (2016) planned an explanatory study of various adaptive serious games frameworks and adaptive engine algorithms. The general taxonomy of this study can be summarized by Figure 5 .

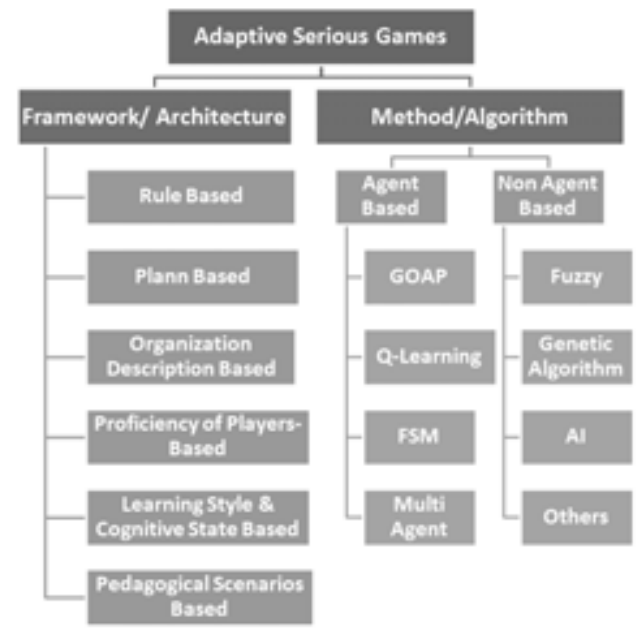

Figure 5. Taxonomy Adaptive Engine for Serious Games (Rasim et al., 2016, p. 3)

\section{ADAPTIVE SERIOUS GAME FRAMEWORK}

A description of some various frameworks that exist in serious games is mentioned below:

- Rule-Based Framework: in this kind of framework, adaptive serious games architechture is based on a player and computer controlled avatars. Generally, when the game is running and for example, there is a fight between two teams, the computer team will change according to the conditions encountered. Thus, thanks to this feedback, new scripts will be created according to the existing rules in the rulebase (Spronck, Ponsen, Sprinkhuizen-Kuyper \& Postma, 2006).

- Plan-Based Framework: in this framework, the games apply the learning problem description components to generate the interaction of narrative through plan-based knowledge representations. This offers the opportunity to the player to accomplish the action even if he does not understand the problem (Thomas \& Young, 2010).

- Organization Description Based Framework: this framework is guided by three main concerns: the trainee, the game objectives and the agents. Its purpose is to adapt the game to the player's abilities in the learning applications and such adaptation should have a direct influence on the trainee. As a result, the adaptation engine generally exploits the information provided by the player and the game model to determine which tasks to adapt and how the agent system responds to these requests (Westra, van Hasselt, Dignum \& Dignum, 2009). 
- Proficiency of Players-Based Framework: in this model, the game tries to launch a test process of the results of the player to propose a level of complexity that well adapts to its abilities. This technique makes it possible to have a dynamic adaptive game that is more effective in terms of achieving the learning objectives (Rasim et al., 2016).

- Learning Style and Cognitive State Based Framework: in this version, the game architecture prepares it to record the learner's cognitive state and learning style in order to offer him the appropriate learning content that meets his cognitive abilities (Chen \& Zhang, 2008).

- Pedagogical Scenarios Based Framework: in this case, the game has a CLES tool (stimulation of cognitive and linguistic elements) aimed at diagnosing the cognitive difficulties of learners during a learning activity. The interest of this analysis is to generate an adaptive learning scenario taking into account the profile of the player (Hussaan \& Sehaba, 2013).

\section{TECHNOLOGY USED IN ADAPTIVE SERIOUS GAME}

The technologies used in serious games are based on adaptive real-time methods that automatically adapt the non-person character in a virtual world to the player's skills and thus, keep it in the golden path area.

- Agent-based Adaptive Engine: because of the complexity of serious games, adaptive engine programming is a difficult task and thus, it requires a control of all elements. In fact, it is interesting to define an agent for each element of the game. Hocine \& Gouaich (2011) say that the algorithms for The agent-based adaptive engine is generally categorized into 2 categories i.e online (adaptation is done at run-time by adaptive behaviour based on the theory of mind, adaptive programming using neural networks and adaptive programming using personality-based technical adaptation) and offline (adaptation done before the start of the game that can use case-based reasoning algorithm and evolutionary algorithm with Finite State Machine as agent behavior techniques).

- Finite state machines (FSM): This abstract machine is used to define a behaviour model with a big number of states which uses a graph composed of nodes and archs. While the node describes a given context for the virtual character, the arch connecting state allows the conditions that are used to change the behaviour between different states (Hocine \& Gouaich, 2011).

- Goal-oriented action planning (GOAP): GOAP uses graph to describe the goals of learning. Each node is made to ensure a dynamic learning purpose during game session. Behavioural trainee avatar is identified by current objective (Hocine \& Gouaich, 2011).

- Q-Learning Based Adaptive Engine: Reinforcement Learning is used to match the trainee's capacities. It can control the system by watching the feedback to set the conditions non-player character (NPC). The best algorithm reinforcement learning is Qdomain learning which is permitted to sort the tasks to assist players to fulfill their best display in entertaiment and learning (Lakshmanan \& Bhatnagar, 2012).

- Multiagent Adaptive Engine: in order to manage the complexity of serious games, current approaches of dynamic adaptive games are calling software agents. They are used to make these educational tools better suited to the player. As a result, agents suggest possible courses of action that are matching their role and context, and the monitor module uses this information together with its evaluation of the player level and the storyline progress to determine the most suitable combination of suggestions (Rasim et al., 2016). 
- Non Agent Based Adaptive Engine:

- Fuzzy Based Adaptive Engine: this game is made for adaptive rehabilitation. Fuzzy system is used for a permanent supervision to avoid that patients assuming wrong postures or performing wrong movements, which may make reeducation destructive. Games have been used to be entirely configurable so that they can be tailored by the doctors the patient needs and the reeducation objectives set (Rasim et al., 2016).

- Genetic Algorithm Based Adaptive Engine: experience Engine is an adaptive engine as applied by Bellotti. The algorithm used in the Experience Engine is a Genetic Algorithm, which is composed of the population, gene, chromosome, operation for selecting parent, crossover operations, and mutation operations (Bellotti, Berta, De Gloria \& Primavera, 2009).

- Al Based Adaptive Engine: A game with Computational Intelligence $(\mathrm{Cl})$, the Monte Carlo Tree Search (MCTS), and Upper Confidence bound for Trees (UCT) algorithms construct dynamic problem adjustment of the non-player character (NPC) in intelligence adaptation (Huang, He, Chang \& Hao, 2010).

\section{Exploration and recommendations}

In this paper, we explored in more detail three possible approaches to this pedagogical support:

- Intrinsic motivation learning

- Situated learning

- Learning from mistakes

If the advantages mentioned are found within these three approaches, they also have their specificities. Thus, a review of their respective implementation examples brings us to several points, summarized in Table 3.

Table 3

Summary of the educational advantages of serious games

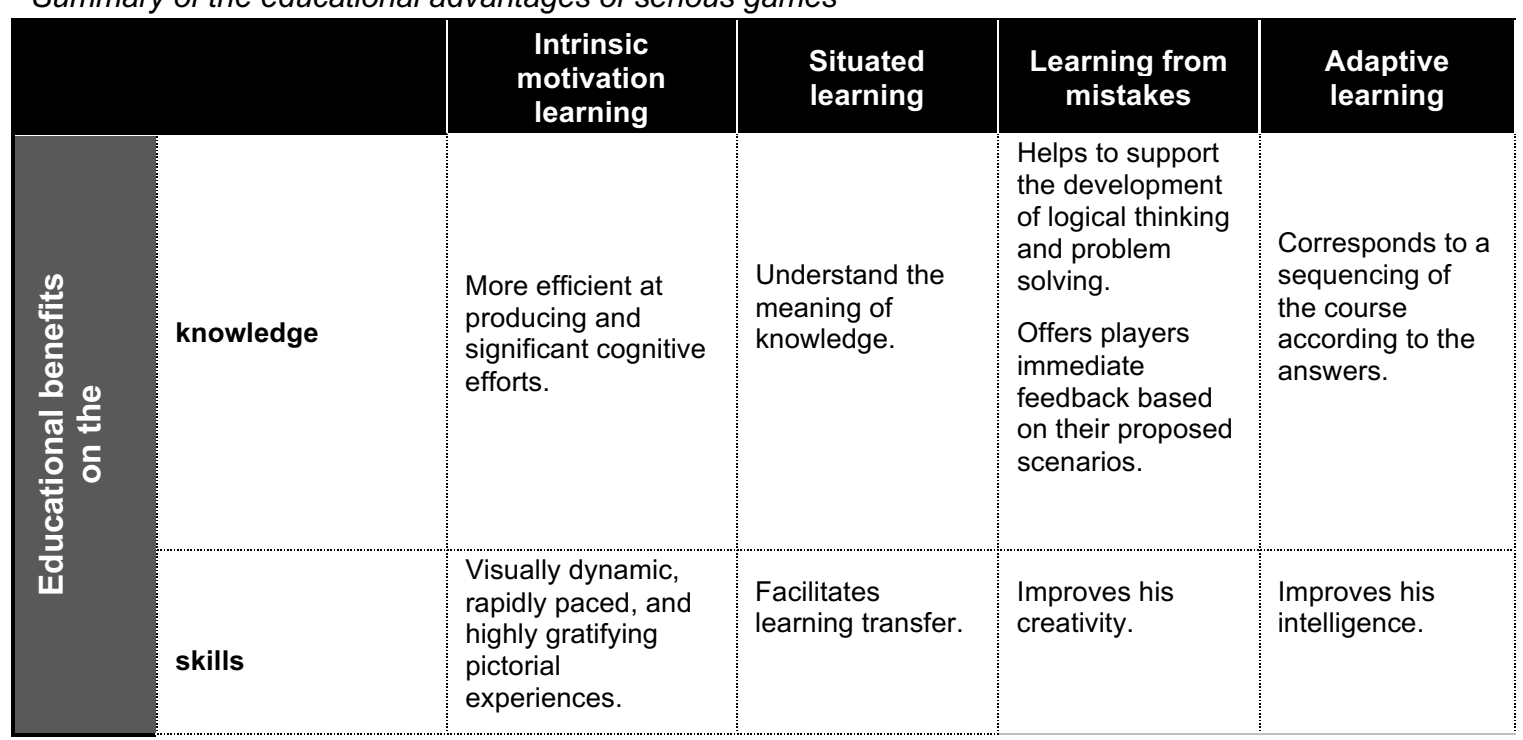


Table 3

Summary of the educational advantages of serious games

\begin{tabular}{|l|l|l|l|l|}
\hline & $\begin{array}{c}\text { Intrinsic } \\
\text { motivation } \\
\text { learning }\end{array}$ & $\begin{array}{c}\text { Situated } \\
\text { learning }\end{array}$ & $\begin{array}{c}\text { Learning from } \\
\text { mistakes }\end{array}$ & \multicolumn{1}{c|}{$\begin{array}{c}\text { Adaptive } \\
\text { learning }\end{array}$} \\
\hline $\begin{array}{l}\text { Autonomy, } \\
\text { Challenge, curiosity, } \\
\text { control and } \\
\text { imagination } \\
\text { (fantasy), deeply } \\
\text { engaging, discovery } \\
\text { and a creative } \\
\text { feeling. }\end{array}$ & $\begin{array}{l}\text { A character who } \\
\text { must find the best } \\
\text { solution to solve a } \\
\text { situation-problem. }\end{array}$ & $\begin{array}{l}\text { Improves his } \\
\text { concentration. }\end{array}$ & Improves his \\
autonomy.
\end{tabular}

However, this work is far from exhaustive. Other approaches than those presented in this article certainly exist, as examples "cross over learning" as one of ten innovations that are on the brink of having a profound influence on education. The concept of crossover learning refers to a comprehensive understanding of learning that bridges formal and informal learning settings and "experientiel learning" aroses in the midnineteenth century as attempts to move away from traditional formal education, where teachers simply presented students with abstract concepts, and toward an immersive method of instruction. Students would "learn by doing", applying knowledge to experience. Likewise, most of the Serious Game's "on-the-ground" use cases are still at modest scales, limited to specific grade levels and disciplines. Yet, one of the teachers' expectations, highlighted by a European study, is the development of a generalized methodology for the use of video games and Serious Games in the classroom. In the light of the studies reviewed in this article, we finally emerge the hypothesis that the Serious Game, because of its richness and diversity, cannot be attached to a unique methodology of educational integration, but implies the necessary coexistence of a multitude of usage approaches. The exploration of the validity of this hypothesis, as well as the deepening of the specificities of the three teaching approaches of the Serious Game that we presented, will be the corner stone of the continuation of our work.

Finaly, in order to take advantage of the educational benefits of serious games and to use them properly in class, it is interesting for the teacher or the trainer to apply certain recommendations, namely:

- The teacher must know about the game used to discover the different possibilities of its use in the classroom. The use of serious games to enhance the teaching methods is still limited, maybe due to the lack of knowledge about the possible assistance to learning.

- The planning in the class is the most important stage and must involve the participant i.e. the teacher to select the content, which should be supported by the use and the choice of the game to meet the goals learning.

- In order to improve the personal autonomy of learners, learning activities involving the use of serious games must foster social and collaborative interactions between students on the one hand and the teacher and his / her students on the other hand.

- the teacher gives the student the opportunity to challenge each other during the process of learning and knowledge construction because the moment of interaction with the game can be an opportunity of motivation among students.

- Serious games integrated by the teacher into his / her learning activities must allow students to interact both individually and collectively while promoting great flexibility in designing learning objectives.

- In serious games, building skills and knowledge is based on experimentation and exploration. As a result, the teacher must view game as a strategic pedagogical medium compatible with the teaching and learning process and not as a mere entertainment tool with an interest in creating a fun-like atmosphere in the class. 
- The application of new teaching strategies can happen properly when teachers view themselves as part and parcel of an active teaching and learning process to accomplish the learning goals.

\section{Conclusion}

Several studies have shown a relevant sample of serous games that have been applied in teaching and training. These types of games have recently been recommended as a real pedagogical tool of supporting education and tend to attract interest, delight and motivate students. Despite its positive educational impact in terms of learning, serious games also suffer from several disadvantages. For example some researchers suggested on the one hand that playing violent video games leads to increases in aggressive thoughts, aggressive effect and physiological provocation, decreased arousal to subsequent depictions of violence and reduced pro-social behaviour. On the other hand, disadvantages have also been associated with playing digital entertainment games, such as difficulties in regulating the amount of time spent playing games, addiction, social isolation and nauseogenic properties of games with head-mounted displays. This ambivalent contribution of this kind of pedagogical tool requires teachers to take the necessary concerns when choosing the game to integrate into their lessons. This must be done in order to achieve the desired educational objectives while enjoying the benefits, and not falling into constraints that can damage the role of the learning situation.

\section{Reference List}

Abt, C. C. (1970). Serious games. New York: The Viking Press.

Aburahma, M. H. \& Mohamed, H. M. (2015). Educational games as a teaching tool in pharmacy curriculum. American journal of pharmaceutical education, 79(4), 59.

Alvarez, J. (2007). Du jeu vidéo au seriousgame: approches culturelle, pragmatique et formelle (Doctoral dissertation, Toulouse 2).

Alvarez, J. \& Djaouti, D. (2010). Introduction au serious game. Paris: Questions théoriques.

Alvarez, J. \& Michaud, L. (2008). Serious Games: Advergaming, edugaming, training and more. Montpellier, France.

Anderson, L. W. (Ed.), Krathwohl, D.R. (Ed.), Airasian, P.W., Cruikshank, K.A., Mayer, R.E., Pintrich, P.R., Raths, J. \& Wittrock, M.C. (2001). A taxonomy for learning, teaching, and assessing: A revision of Bloom's Taxonomy of Educational Objectives (Complete edition). New York: Longman

Annetta, L. A., Minogue, J., Holmes, S. Y. \& Cheng, M. T. (2009). Investigating the impact of video games on high school students' engagement and learning about genetics. Computers \& Education, 53(1), 7485.

Astolfi, J. P. (1997). L'erreur: un outil pour enseigner. Paris: ESF

Baranowski, T., Baranowski, J., Cullen, K. W., Marsh, T., Islam, N., Zakeri, I., ... \& Demoor, C. (2003). Squire's Quest!: Dietary outcome evaluation of a multimedia game. American journal of preventive medicine, 24(1), 52-61.

Beck, J. C. \& Wade, M. (2004). Got game: How the gamer generation is reshaping business forever. Boston: Harvard Business School Press.

Becker, K. \& Parker J. R. (2006). Digital Games as Simulations. Paper presented at the 2006 SCS International Conference on Modeling and Simulation - Methodology, Tools, Software Applications. Calgary, Alberta. 
Bellotti, F., Berta, R., De Gloria, A. \& Primavera, L. (2009). Adaptive experience engine for serious games. IEEE Transactions on Computational Intelligence and Al in Games, 1(4), 264-280.

Bieliková, M., Divéky, M., Jurnečka, P., Kajan, R. \& Omelina, L. U. (2008). Automatic generation of adaptive, educational and multimedia computer games. Signal, image and video processing, 2(4), 371-384.

Buckingham, D. \& Scanlon, M. (2000, November). That is edutainment: Media, pedagogy and the marketplace. Paper presented to the International Forum of Researchers on Young People and the Media, 26-29 November 2000. Sydney, Australia.

Checola, L. (2008, March 24). Les jeux sérieux, un marché en expansion. Retrieved from Le Monde website: www.lemonde.fr

Cheng, M. T. \& Annetta, L. (2012). Students' learning outcomes and learning experiences through playing a Serious Educational Game. Journal of Biological Education, 46(4), 203-213.

Chen, S. \& Zhang, J. (2008, December). The adaptive learning system based on learning style and cognitive state. In 2008 International Symposium on Knowledge Acquisition and Modeling (p. 302-306). IEEE.

Cohard, P. (2013). Conception et évaluation d'un serious game pour le personnel des EHPAD (Doctoral dissertation, Université de Paris Ouest, Nanterre, France).

Crawford, C. (1982). The Art of Computer Game Design. Vancouver, WA : Washington State University Vancouver, Retrieved from https://www.digitpress.com/library/books/book art of computer game design.pdf.

Csikszentmihalyi, M. (1990). Flow: the psychology of optimal experience. New York: Harper \& Row.

Deci, E. L. (1971). Effects of externally mediated rewards on intrinsic motivation. Journal of personality and Social Psychology, 18(1), 105.

Deterding, S., Dixon, D., Khaled, R. \& Nacke, L. (2014). Du game design au gamefulness: définir la gamification. Sciences du jeu, 2014(2).

Dewey, J. (1933). How we think: A restatement of the relation of reflective thinking to the educative process. D.C. Heath.

Djaouti, D. (2011). Serious Game Design: considérations théoriques et techniques sur la création de jeux vidéo à vocation utilitaire (Doctoral dissertation, Université de Toulouse, Université Toulouse III-Paul Sabatier). Retrieved from http://www.ludoscience.com/files/these djaouti.pdf

Djaouti, D., Alvarez, J. \& Jessel, J. P. (2011). Classifying serious games: the G/P/S model. In P. Felicia (dir.), Handbook of research on improving learning and motivation through educational games: Multidisciplinary approaches, 118-136

Djaouti, D., Alvarez, J., Jessel, J. P., Methel, G. \& Molinier, P. (2008). A gameplay definition through videogame classification. International Journal of Computer Games Technology, 2008(4). https://doi.org/10.1155/2008/470350

Egenfeldt-Nielsen, S. (2007). Third generation educational use of computer games. Journal of Educational Multimedia and Hypermedia, 16(3), 263-281.

Foreman, J. (2003). Next-Generation Educational Technology versus the Lecture. EDUCAUSE Review, 35(5),12-22.

Frété, C. (2015). Le potentiel du jeu vidéo pour l'éducation. Éditions universitaires européennes.

Frossard, F., Barajas, M. \& Trifonova, A. Jeux sérieux : quels impacts sur la créativité en classe? ARGOS 49(18).. Retrieved from http://www.educ-revues.fr/ARGOS/AffichageDocument.aspx?iddoc=41670

Garris, R., Ahlers, R. \& Driskell, J. E. (2002). Games, motivation, and learning: A research and practice model. Simulation \& gaming, 33(4), 441-467.

George, S., Michel, C., Serna, A. \& Bisognin, L. (2014). Évaluation de l'impact d'un jeu sérieux en réalité mixte. Sciences et Technologies de l'Information et de la Communication pour l'Éducation et la Formation, 2014(21), 1-25. 
Hauge, J. B., Bellotti, F., Berta, R., Carvalho, M. B., De Gloria, A., Lavagnino, E., ... \& Ott, M. (2013). Field assessment of serious games for entrepreneurship in higher education. Journal of convergence information technology, 8(13).

Higgins, S. (2000). The logical zoombinis. Teaching thinking, 1(1), 12-15.

Hocine, N. \& Gouaich, A. (2011). A survey of agent programming and adaptive serious games. Retrieved from https://hal-lirmm.ccsd.cnrs.fr/lirmm-00577722/document

Huang, W., He, S., Chang, D. \& Hao, Y. (2010, August). Dynamic difficulty adjustment realization based on adaptive neuro-controlled game opponent. In Third International Workshop on Advanced Computational Intelligence (p. 66-71). IEEE.

Hussaan, A. M. \& Sehaba, K. (2013, July). Adaptive serious Game for Rehabilitation of persons with cognitive disabilities. In 2013 IEEE 13th International Conference on Advanced Learning Technologies (p. 6569). IEEE.

Jantke, K. P. \& Gaudl, S. (2010, December). Taxonomic contributions to digital games science. In Games Innovations Conference (ICE-GIC), 2010 International IEEE Consumer Electronics Society's (p. 1-8). IEEE.

Jenkins, H., Camper, B., Chisholm, A., Grigsby, N., Klopfer, E., Osterweil, S., ... \& Guan, T. C. (2009). From serious games to serious gaming. In U. Ritterfeld, M. Cody \& P.Vorderer (Eds.), Serious Games: Mechanisms and Effects.(p. 448-468). Routledge : New York.

Jonassen, D. H., Campbell, J. P. \& Davidson, M. E. (1994). Learningwith media: Restructuring the debate. Educational technology research and development, 42(2), 31-39.

Kapp, K. M. (2012). The gamification of learning and instruction: game-based methods and strategies for training and education. John Wiley \& Son

Kasbi, Y. (2012). Les serious games: une révolution. Edipro.

Khouna, J., Ajana, L., Rhazal, A.\& El Hajjami, A. (2017). Introducing educational games in the teaching of physics in Moroccan secondary schools. Journal of Research \& Method in Education (IOSR-JRME), 7(4), 19-28.

Kim, B. (2015). Designing gamification in the right way. Library Technology Reports, 51(2), 29-35.

Kirriemuir, J. \& McFarlane, A. (2004). Literature review in games and learning. Retrieved from https://telearn.archives-ouvertes.fr/hal-00190453/document

Kirschner, P. A., Sweller, J., \& Clark, R. E. (2006). Why minimal guidance during instruction does not work: An analysis of the failure of constructivist, discovery, problem-based, experiential, and inquiry-based teaching. Educational psychologist, 41(2), 75-86.

Kolb, D. A. (1984). Experiential learning. Englewood Cliffs (NJ): Prentice-Hall.

Kozanitis, A. (2005). Les principaux courants théoriques de l'enseignement et de l'apprentissage: un point de vue historique. Bureau d'Appui Pédagogique, École polytechnique de Montréal. Retrieved from https://www.polymtl.ca/appui-pedagogique/ressources-pedagogiques/documents-consulter

Krathwohl, D.R., Bloom, B.S. \& Masia, B.B. (1964). Taxonomy of educational objectives: Handbook II: Affective domain. New York: David McKay Co.

Laamarti, F., Eid, M. \& El Saddik, A. (2014). An overview of serious games. International Journal of Computer Games Technology, 2014(11). https://doi.org/10.1155/2014/358152

Lakshmanan, K. \& Bhatnagar, S. (2012, October). A novel Q-learning algorithm with function approximation for constrained Markov decision processes. In 2012 50th Annual Allerton Conference on Communication, Control, and Computing (Allerton) (p. 400-405). IEEE.

Lave, J. (1988). Cognition in practice: Mind, mathematics and culture in everyday life. Cambridge: University Press. 
Lave, J. (1991). Situating learning in communities of practice. Perspectives on socially shared cognition, 1991(2), 63-82.

Lave, J. \& Wenger, E. (1991). Situated learning: Legitimate peripheral participation. Cambridge universitypress.

Lavergne Boudier, V. \& Dambach, Y. (2010). Seriousgame, la révolution pédagogique. Paris, France : Hermès Sciences.

Lavigne, M. (2014). Les faiblesses ludiques et pédagogiques des seriousgames. In Actes du Colloque international TICEMED, 9.

Lunce, L. M. (2006). Simulations: Bringing the benefits of situated learning to the traditional classroom. Journal of Applied Educational Technology, 3(1), 37-45.

Malone, T. W. (1981). Toward a theory of intrinsically motivating instruction. Cognitive science, 5(4), 333-369.

Malone, T. W. \& Lepper, M. R. (1987). Making learning fun: a taxonomy of intrinsic motivations for Learning. In R.E. Snow \& M.J. Farr (Eds.), Aptitude, learning and instruction: cognitive and affective process (3, 222-253). Hilsdale (N. J.), Erlbaum.

Maxis. (2013). SimCity [Software]. Retrieved from https://www.ea.com/fr-fr/games/simcity

McArthur, V. \& Teather, R. J. (2015, October). Serious mods: A case for modding in serious games pedagogy. In 2015 IEEE Games Entertainment Media Conference (GEM) (p. 1-4). IEEE.

Mellier, D. (2007). Harris Paul L. L'imagination chez l'enfant : son rôle crucial dans le développement cognitif et affectif. Revue française de pédagogie, 161(4), 126-127. Retrieved from https://www.cairn.info/revuefrancaise-de-pedagogie-2007-4-page-126.htm

Michaud, L., Alvarez, J., Alvarez, V. \& Djaouti, D. (2012). Serious games: enjeux, offre et marché. IDATE (Ed.).

Michel, H., Kreziak, D. \& Héraud, J. M. (2009). Évaluation de la performance des Serious Games pour l'apprentissage: Analyse du transfert de comportement des éleveurs virtuels de Vacheland. Systèmes d'information \& management, 14(4), 71-86.

Miller, L. M., Chang, C. I., Wang, S., Beier, M. E. \& Klisch, Y. (2011). Learning and motivational impacts of a multimedia science game. Computers \& Education, 57(1), 1425-1433.

Monterrat, B., Lavoué, E., \& George, S. (2012, October). Learning Game 2.0: Support for game modding as a learning activity. In Proceedings of the 6th European Conference on Games Based Learning (p. 340347). Retrieved from https://hal.archives-ouvertes.fr/hal-00738749/file/ECGBL-2012-MonterratLavoue-George.pdf

Montessori, M. (1946). Education for a new world. India: Kalakshetra Press.

Mouaheb, H., Fahli, A., Moussetad, M. \& Eljamali, S. (2012). The serious game: what educational benefits?. Procedia-Social and Behavioral Sciences, 2012(46), 5502-5508.

Narayanasamy, V., Wong, K. W., Fung, C. C. \& Rai, S. (2006). Distinguishing games and simulation games from simulators. Computers in Entertainment (CIE), 4(2), 9.

Natkin, S. (2009). Du ludo-éducatif aux jeux vidéo éducatifs. Les dossiers de l'ingénierie éducative, 2009(65), $12-15$.

Neufeldt, V. \& Sparks, A. N. (Eds.). (2002). Webster's new world dictionary. Simon and Schuster.

Papastergiou, M. (2009). Digital game-based learning in high school computer science education: Impact on educational effectiveness and student motivation. Computers \& education, 52(1), 1-12.

Piaget, J. (1929). The child's concept of the world. London: Routledge \& Kegan Paul.

Piaget, J. (1994). La formation du symbole chez l'enfant: imitation, jeu et rêve, image et représentation (8ème éd.). Paris: Neuchatel. Delachaux et Niestlé 
Przybylski, A. K., Rigby, C. S. \& Ryan, R. M. (2010). A motivational model of video game engagement. Review of general psychology, 14(2), 154.

Rankin, J. R. \& Sampayo, S. (2008). A survey of real-world applications of serious games technology. Proceedings of the Simulation-Maximising Organisational Benefits (SimTect'08) (p. 305-311)

Rapeepisarn, K., Wong, K. W., Fung, C. C. \& Depickere, A. (2006). ACM International Conference Proceeding Series (vol. 207).

Ratan, R. A. \& Ritterfeld, U. (2009). Classifying serious games. In Serious games (p. 32-46). Routledge.

Rasim, Langi, A. Z., Munir, \& Rosmansyah, Y. (2016, February). A survey on adaptive engine technology for serious games. In AIP Conference Proceedings (Vol. 1708, No. 1, p. 050003). AIP Publishing. https://doi.org/10.1063/1.4941161

Relentless Software. (2008). Buzz! Quiz TV game [Software].Retrieved from https://www.jeuxactu.com/testbuzz-quiz-tv-33249.htm

Rideout, V. J., Foehr, U. G. \& Roberts, D. F. (2010). Generation M 2: Media in the Lives of 8-to 18-Year-Olds. Henry J. Kaiser Family Foundation.

Rieber, L. P., Smith, L. \& Noah, D. (1998). The value of serious play. Educational Technology, 38(6), 29-37.

Sanchez, E., Ney, M. \& Labat, J. M. (2011). Jeux sérieux et pédagogie universitaire: de la conception à l'évaluation des apprentissages. Revue internationale des technologies en pédagogie universitaire/International/International Journal of Technologies in Higher Education, 8(1-2), 48-57.

Sánchez, J. \& Olivares, R. (2011). Problem solving and collaboration using mobile serious games. Computers \& Education, 57(3), 1943-1952.

Sauvé, L. (2008, December). Concevoir des jeux éducatifs en ligne: un atout pédagogique pour les enseignants. In Communication du Colloque Scientifique Ludovia (Vol. 27).

Sawyer, B. (2002). Serious games: improving public policy through game-based learning and simulation. USA, Woodrow Wilson International Center for Scholars. Retrieved from https://fr.scribd.com/document/38259791/Serious-Games-Improving-Public-Policy-throughGamebased-Learning-and-Simulation

Sawyer, B. \& Smith, P. (2008, February). Serious games taxonomy [Slides].Serious Games Summit at the Game Developers Conference.(p. 1-54). Retrieved from https://thedigitalentertainmentalliance.files.wordpress.com/2011/08/serious-games-taxonomy.pdf

SCE London Studio (2008). Singstar PS3 karaoke [Software]. Retrieved from https://www.playstation.com/enus/games/singstar-ps3/

Shaftel, J., Pass, L. \& Schnabel, S. (2005). Math games for adolescents. Teaching Exceptional Children, 37(3), 25-30

Schmoll, L. (2017). Penser l'intégration du jeu vidéo en classe de langue. Recherche et pratiques pédagogiques en langues de spécialité. Cahiers de l'Apliut, 36(2).

Shute, V. J. \& Ke, F. (2012). Games, learning, and assessment. In Assessment in game-based learning (p. 4358). Springer New York.

Spronck, P., Ponsen, M., Sprinkhuizen-Kuyper, I. \& Postma, E. (2006). Adaptive game Al with dynamic scripting. Machine Learning, 63(3), 217-248.

Squire, K. D. (2008). Video game-based learning: An emerging paradigm for instruction. Performance Improvement Quarterly, 21(2), 7-36.

St-Pierre, R. (2010). Des jeux vidéo pour l'apprentissage? Facteurs de motivation et de jouabilité issus du game design. DistanceS, 12(1), 4-26.

Thomas, J. M. \& Young, R. M. (2010). Annie: Automated generation of adaptive learner guidance for fun serious games. IEEE Transactions on Learning Technologies, 3(4), 329-343.

Thorndike, E. L. (1931). Human Learning, New York: Appelton-Century-Crofts. 
Trollip, S. R. et alessi, S. M. (2001). Multimedia for learning: methods and development. Massachusetts: Allyn \& Bacon.

Tobias, S., Fletcher, J. D., Dai, D. Y. \& Wind, A. P. (2011). Review of research on computer games. Computer games and instruction, 127(222).

Vallerand, R. J., Blais, M. R., Brière, N. M. \& Pelletier, L. G. (1989). Construction et validation de l'échelle de motivation en éducation (EME). Canadian Journal of Behavioural Science/Revue canadienne des sciences du comportement, 21(3), 323.

Vallerand, R. J. \& Halliwell, W. R. (1983). Formulations théoriques contemporaines en motivation intrinsèque: Revue et critique. Canadian Psychology/Psychologie canadienne, 24(4), 243.

Van Horn, R. (2007). Educational Games. Phi Delta Kappan, 89(1), 73-74.

Vogel, J. J., Vogel, D. S., Cannon-Bowers, J., Bowers, C. A., Muse, K. \& Wright, M. (2006). Computer gaming and interactive simulations for learning: A meta-analysis. Journal of Educational Computing Research, 34(3), 229-243.

Wastiau, P., Kearney, C. \& Van den Berghe, W. (2009). Quels usages pour les jeux électroniques en classe?, European Schoolnet.

Wenger, E. (2005). La théorie des communautés de pratique, apprentissage, sens et identité. Québec, Canada: Les Presses de l'Université Laval.

Westra, J., van Hasselt, H., Dignum, F. \& Dignum, V. (2009, May). Adaptive serious games using agent organizations. In F. Dignum., J. Bradshaw, B. Silverman \& W. van Doesburg (Eds.), International Workshop on Agents for Games and Simulations (p. 206-220). Springer, Berlin, Heidelberg. https://doi.org/10.1007/978-3-642-11198-3 14

Whitebread, D. (1997). Developing children's problem-solving: the educational uses of adventure games. In A. McFarlane (Ed.), Information technology and Authentic Learning. London: Routledge.

Wix, A. (2012). Jouer en classe, est-ce bien sérieux ? Bilan de l'expérimentation académique sur les usages de jeux sérieux au collège et au lycée. Académied'Aix-Marseille.

Wouters, P., Van Nimwegen, C., Van Oostendorp, H. \& Van Der Spek, E. D. (2013). A meta-analysis of the cognitive and motivational effects of serious games. Journal of educational psychology, 105(2), 249.

Zyda, M. (2005). From visual simulation to virtual reality to games. Computer, 38(9), 25-3 